\title{
BIBLIOTEKI PARAFIALNE W DIECEZJI PODLASKIEJ (1918-1939)
}

Do najważniejszych zadań, przed którymi stanął Kościół katolicki w odrodzonej Polsce, należało przystosowanie jego działalności duszpasterskiej do rosnącej polaryzacji postaw społeczno-religijnych oraz podniesienie poziomu kultury religijnej ogółu wiernych, która kontrastowała z ogólnym poziomem kultury upowszechniającej się wśród ludności wraz z systematycznym rozwojem szkolnictwa, prasy i czytelnictwa. Poszukiwaniem nowych form oddziaływania duszpasterskiego i życia religijnego zajęto się jeszcze $w$ XIX $w$. W sposób wyraźny do ożywienia działań w tym względzie przyczynił się carski ukaz tolerancyjny z 30 IV 1905 r., zapewniający wolność religijną mieszkańcom Królestwa Polskiego, a kapłanom możliwość wyjścia w swej pracy duszpasterskiej poza mury świątyń.

Zajęto się m.in. zakładaniem bibliotek i czytelni parafialnych oraz organizacją kolportażu prasy religijnej. Jako pierwszy z postulatem zorganizowania biblioteki w każdej parafii wystąpił na łamach „Wiadomości Pasterskich" w sierpniu 1905 r. ks. Marian Fulman, kapłan diecezji włocławskiej (w latach 1918-1945 - ordynariusz diecezji lubelskiej) ${ }^{\uparrow}$. Wskazał on także na potrzebę utworzenia we wszystkich diecezjach Królestwa Polskiego specjalnych towarzystw, które pomagałyby księżom w organizowaniu bibliotek w parafiach ${ }^{2}$. Towarzystwa takie powstały w archidiecezji warszawskiej i diecezji płockiej. Z zamiarem utworzenia towarzystw bibliotek parafialnych nosili się także ordynariusze innych diecezji ${ }^{3}$. Wladze carskie po 1907 r. nie były jednak już skłonne do udzielania zezwoleń na taką działalność. Zakładanie bibliotek parafialnych w pozostałych diecezjach było więc znacznie trudniejsze. Trzeba było bowiem zabiegać o uzyskanie zezwolenia na otwarcie każdej biblioteki. Tak też było w diecezji podlaskiej, skasowanej ukazem carskim z 22 V 1867 r., której teren przyłączono do diecezji lubelskiej. W wyniku indywidualnych starań duchowieństwa doszło do powstania bibliotek parafialnych m.in. w Adamowie, Liwie i Prostyni ${ }^{4}$. Równolegle odbywała się akcja zakładania bibliotek, zazwyczaj o podobnym profilu, przez organizacje katolickie i religijne, jak np. Związek Katolicki, Towarzystwo Pomocy Ubogim itp. Największą aktywność w tym względzie przejawiał Zwiazzek Katolicki, który zorganizował biblioteki: w Maciejowicach, Rykach, Domanicach, Woli Gułowskiej, Korytnicy Węgrowskiej, Wilczyskach, Wyszkowie, Starej Wsi i Wojcieszkowie ${ }^{5}$.

Akcja zakładania bibliotek parafialnych uległa zahamowaniu w latach poprzedzających wybuch I wojny światowej. Do jej ponownego ożywienia doszło po ustąpieniu Rosjan i zajęciu Podlasia przez wojska niemieckie. W latach 1915-1918 powstały bitblioteki parafialne, m.in. w Koczowie, Żelechowie, Wohyniu, Rozbitym 
Kamieniu i Węgrowie ${ }^{6}$. Początek niektórym bibliotekom, m.in. w Wyszkowie i Wilczyskach, dały księgozbiory po Zwiazku Katolickim.

24 IX 1918 r. diecezję podlaską oddzielono od lubelskiej, przywracając jej samodzielność administracyjną. Rządy w diecezji objał bp Henryk Przeździecki, który już w swym pierwszym liście pasterskim do duchowieństwa i wiernych wskazał na pilną potrzebę podniesienia poziomu kultury religijnej ${ }^{7}$. Znacznie szerzej problemem tym zajęli się biskupi polscy w liście z 20 | 1919 r., skierowanym do duchowieństwa w zwiazku z pierwszymi wyborami do Sejmu Ustawodawczego

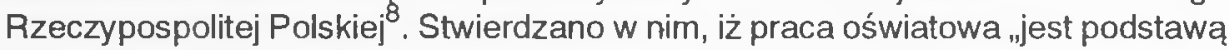
wszelkiej innej, bez niej wszelka inna praca jest tylko ognikiem, który na chwilę wybuchnie i gaśnie. Bardzo wskazane jest zakładanie bibliotek parafialnych, które się stają ogniskiem oświatowego ruchu ludu. Zogromnym pożytkiem łączyć można czytanie i wypożyczanie książek z odczytami dla ludu, połączonymi z dyskusją (...). W ten sposób wszystkie kwestie, wątpliwości ludu przez żywe słowa i dyskusje mogą być wyświetlone, a walka z nieoświeceniem i ciemnotą ludu, przez wrogów Kościoła wyzyskiwana, skutecznie jest prowadzona"9 . Do powyższych postulatów ustosunkowali się księża dziekani diecezji podlaskiej na swej piątej konferencji w Siedlcach 21 VIII 1919 r. Aby zachęcić duchowieństwo i wiernych do pracy społeczno-oświatowej, postanowiono znaleźć w każdym dekanacie jedną parafię i zorganizować w niej m.in. bibliotekę i kolportaż prasy religijnej, co miało stanowić przykład dla innych ${ }^{10}$. Zamiar ten udało się zrealizować tylko częściowo. W latach 1919-1922 powstały biblioteki parafialne, m.in.: w Łosicach, Grębkowie, Miedznej, Kornicy, Sarnakach, Mostowie, Krześlinie, Komarówce, Radoryżu, Zofiborze i Łaskarzewie $^{11}$. Ważne znaczenie dla rozwoju bibliotek parafialnych $w$ diecezji podlaskiej miał jej I Synod (1923r.), który zobowiazywal proboszczów do popierania i rozwijania pracy oświatowej (statut 187) ${ }^{12}$. W przyjętej przez Synod „Instrukcji o pracy duszpasterskiej" stwierdzano, iż: "Dobrze zorganizowana parafia nie może się obejść bez biblioteki parafialnej"13. Duchowieństwo zobowiązano także do popierania bibliotek stowarzyszeń katolickich.

W diecezji podlaskiej w 1928 r., tj. w pięć lat po Synodzie, było 78 bibliotek parafialnych (tab. 1). Odsetek parafii posiadających biblioteki wynosił $38,4 \%$. Najwięcej bibliotek było w dekanatach: liwskim, łukowskim, siedleckim katedralnym, sokołowskim, węgrowskim i żelachowskim, co było spowodowane większym zainteresowaniem ich działalnością ze strony wiernych. Na terenie wymienionych dekanatów zamieszkiwała duża grupa drobnej szlachty, mocno związanej z Kościołem, która była nie tylko religijna, ale i praktykująca ${ }^{14}$. Zagrodowcy angażowali się chętnie w działalność organizacji katolickich i religijnych, do których w diecezji podlaskiej w 1928 r. należało przeszło 200 tys. osób ${ }^{15}$. Niewiele bibliotek było w dekanatach: bialskim, janowskim, parczewskim, wisznickim, międzyrzeckim i włodawskim, gdzie większość wiernych stanowili byli unici, którzy stosunkowo niedawno przyjęli obrządek łaciński ${ }^{16}$.

Często w domu parafialnym - w jednej sali - znajdowało się kilka bibliotek o tym samym lub podobnym profilu księgozbiorów, należących do różnych organizacji katolickich i religijnych. Posiadały one zazwyczaj niewiele książek, dawno już wyczytanych. W tej sytuacji wielu duszpasterzy, mimo synodalnych zaleceń, rezyg- 
nowało z zakładania jeszcze jednej małej biblioteczki o podobnym profilu, pozbawionej możliwości dalszego rozwoju. W połowie lat 30-tych Diecezjalny Instytut Akcji Katolickiej (DIAK) w Siedlcach zaproponował skomasowanie księgozbiorów bibliotek: parafialnych, stowarzyszeń katolickich i organizacji religijnych oraz utworzenie w ich miejsce jednej wspólnej biblioteki, którą miał kierować parafialny zarząd Akcji Katolickiej. Organizacje katolickie i religijne miały posiadać jedynie biblioteczki podręczne, zaopatrzone w literaturę dotyczącą ich działalności. Propozycja DIAK spotkała się jednak $z$ niewielkim odzewem. Wspólne biblioteki udało się zorganizować tylko w kilkunastu parafiach, m.in.: Ganwolinie, Górznie, Łukowie (parafia Przemienienia Pańskiego) i Międzyrzecu Podl. (parafia św. Mikołaja) ${ }^{17}$.

Znacznie więcej w latach 30-tych powstało „zwykłych" bibliotek parafialnych. Miał miejsce także proces odwrotny. Szereg bibliotek przerwało działalność. Niektóre z nich po kilkuletniej przerwie ją wznowiły. W latach 30-tych powstały biblioteki parafialne: w Suchożebrach - dekanat siedlecki katedralny, Siedlcach, Radomyślu i Hołubli - dek. siedlecki św. Stanisława, Białej Podl. (parafie: Narodzenia NMP i św. Anny), Łomazach, Łukowcach, Woskrzenicach, Ortlu Książęcym i Ortlu Królewskim - dek. bialski, Wildze, Goźlinie, Warszawicach, Ostrówku i Trąbkach - dek. garwoliński, Konstantynowie - dek. janowski, Samogoszczy, Sobolewie i Życzynie - dek. łaskarzewski, Niemojkach i Próchenkach - dek. łosicki, Woli Gułowskiej, Jeleńcu i Jedlance - dek. łukowski, Polskiej Woli i Witorożu - dek. międzyrzecki, Milanowie, Kolanie i Gęsi - dek. parczewski, Kocku - dek. radzyński, Kożuchówku - dek. sokołowski, Seroczynie - dek. sterdyński, Pawłowicach i Sobieszynie - dek. stężycki, Malowej Górze, Tucznej, Terespolu i Kodniu - dek. terespolski, Wisznicach, Rozwadówce, Horodyszczu i Motwicy - dek. wisznicki, Włodawie, Hannie i Brussie - dek. włodawski oraz Wandowie - dek. żelechowski ${ }^{18}$. Przestały natomiast działać biblioteki: w Domanicach, Niwiskach i Seroczynie - dek. siedlecki katedralny, Pruszynie - dek. siedlecki św. Stanisława, Czerwonce Liwskiej - dek. liwski, Górkach, Hadynowie i Przesmykach - dek. łosicki, Serokomli - dek. łukowski, Parczewie - dek. parczewski, Komarówce - dek. radzyński, Czerwonce Grochowskiej, Knychówku i Niecieczy - dek. sokołowski, Stężycy, Rykach i Żabiance - dek. stężycki, Sadownem - dek. węgrowski, Wereszczynie - dek. włodawski oraz Zwoli i Stoczku Łuk. - dek. żelechowski ${ }^{19}$. Spośród nich po kilku latach wznowiły działalność biblioteki: w Górkach, Nieciecz». Zwoli i Stoczku Łuk., a z wcześniej powstałych: w Łaskarzewie, Łosicach i Zofiborze ${ }^{20}$. Nie powiodły się, z powodu braku środków, próby zorganizowania bibliotek w parafiach obrądku wschodniosłowiańskiego (neounickich) ${ }^{21}$.

Nadzór nad działalnością bibliotek parafialnych, zgodnie z synodalną „Instrukcją o pracy duszpasterskiej" należal do księży proboszczów, którzy przeważnie też nimi bezpośrednio zarządzali. Częścią bibliotek kierowały osoby świeckie: nauczyciele (Kornica, Kłoczów, Zofibór, Wyszków) i organiści (Malowa Góra, Radoryż, Skibniew, Łysobyki, Knychówek, Mokobody, Kopcie), członkowie III Zakonu św. Franciszka, bractw i kólek Żywego Różańca (parafia św. Anny w Białej Podl., Trąbki, Kożuchówek, Sarnaki) lub Stowarzyszeń Młodzieży Polskiej (Rozbity Kamień, Łosice, Krześlin, Łomazy, Ryki, Seroczyn, Horodyszcze, Ulan, Gęś, Jeziory-Sobienie, Trzebieszów, Wandów, Wilga, Nieciecz) ${ }^{22}$. 
Środki na zakup i oprawę książek oraz sprzęt biblioteczny czerpano najczęściej z funduszu parafialnego i funduszu księży proboszczów, dobrowolnych ofiar wiernych, wpływów ze składek i opłat czyteiników oraz imprez dochodowych. Świadczenia z funduszu parafialnego na rzecz bibliotek nie miały jednak charakteru stałego. W utrzymaniu bibliotek parafialnych partycypowały niekiedy organizacje katolickie i religijne. Wiele bibliotek borykało się, o czym mówią sprawozdania z wizytacji biskupich, z poważnymi trudnościami finansowymi. Były i takie biblioteki, które z powodu braku pieniędzy na zakup nowości, posługiwały się raz zakupionym lub ofiarowanym księgozbiorem. Stan źródeł nie pozwala jednak na przeprowadzenie dokładniejszej analizy ich sytuacji finansowej. Wiadomo jedynie o wysokości wydatków niektórych z nich w 1929 r. Siedem bibliotek parafialnych, spośród 18 objętych spisem Ministerstwa Wyznań Religijnych i Oświecenia Publicznego, wydało ogółem 1916 złl, pięć nie miało wydatków, a o sześciu pozostałych brak bliższych informacji ${ }^{23}$. Dochód biblioteki parafii Przemienienia Pańskiego w Łukowie, największej tego typu placówki w diecezji podlaskiej, wynosił w okresie od 1 XI 1933 do 1 V 1935 r. -1013 zł, zaś w 1937 r. $-4134 z^{24}$. Pochodził on głównie $z$ ofiar wiernych na rzecz biblioteki oraz wpływów z imprez dochodowych. Większość pieniędzy przeznaczano na zakup i oprawę książek.

Biblioteki parafialne mieściły się przeważnie na plebaniach i w kancelariach parafialnych. Niektóre znajdowały się w zakrystiach (Trąbki, parafia św. Anny w Białej Podl.) i organistówkach (Sarnaki, Ryki, Seroczyn), mieszkaniach prywatnych (Żelechów), szkołach (Rozbity Kamień, Skibniew) i spółdzielniach (Radzyń Podl.), radziej w Domach Katolickich (Kłoczów, Korytnica Łask.) lub Ludowych (Skórzec) ${ }^{25}$.

Księgozbiory bibliotek parafialnych były niewielkie. 78 bibliotek, jakie istniały w 1928 r., miało ogótem 18577 t. (tab. 1); 14 bibliotek posiadało księgozbiory liczące od 20 do 50 t.; 13 - od 51 do 100 t.; 20 - od 101 do 200 t.; 12 - od 201 do 300 t.; 5 - od 301 do 400 t.; 2 - od 401 do 500 t.; 5 - od 501 do 600 t.; 3 - od 601 do 700 t.; 2 - od 701 do 800 t. i 2 - od 801 do 900 t.; 1501 t. w 1937 r. miała biblioteka parafii Przem. Pańskiego $w$ Łukowie $^{26}$.

W księgozbiorach bibliotek parafialnych, jak wynika z akt wizytacji biskupich, dominowała literatura religijna $i$ beletrystyka oraz ksią̇̇i $z$ dziedziny historii $i$ rolnictwa $^{27}$. Księgozbiór biblioteki parafii Przem. Pańskiego w Łukowie podzielony był na 12 działów: I - powieściowy, II - przygody, podróże, wojny itp., III - naukowy, IV - życiorysy, V - religijny, VI - dla inteligencji, VII - żydoznawczy, VIII - dla szkół powszechnych, IX - dla gimnazjów, X - zagadnień seksualnych, XI - rolniczy, XII - społeczno-ekonomiczny ${ }^{28}$.

Księża starali się w różny sposób oddziaływać na wiernych, aby zachęcić ich do korzystania z bibliotek parafialnych oraz do czytania ksiażek i prasy religijnej. Przynajmniej raz $w$ roku, zgodnie z zaleceniami Kurii Biskupiej w Siedlcach, wygłaszali kazania, ukazujące pożytek płynący z czytania książek i prasy. Przy różnych okazjach prowadzili też z wiernymi stosowne na ten temat rozmowy. Wielu księży wykorzystywało do tego coroczną wizytę duszpasterską (kolędę), składana wiernym w okresie między Bożym Narodzeniem i środą popielcową. W propagowaniu bibliotek i czytelnictwa współdziałali z księżmi członkowie organizacji katolickich i religijnych. 
Biblioteki parafialne były ogólnie dostępne. Czytelnicy mieli, w myśl zaleceń „Instrukcji o pracy duszpasterskiej”, wnosić opłaty za korzystanie, „chociażby i bardzo małe, aby nauczyli się cenić książkę i przyczyniali się do wzrostu księgozbioru" ${ }^{\prime 2}$. Większość bibliotek, aby zachęcić wiernych do czytania oraz zważywszy na ich trudną sytuację materialną, nie pobierała jednak żadnych opłat. Opłaty za korzystanie ze zbiorów bibliotecznych składały się z wpisowego, abonamentu i kaucji. Rzadko te trzy rodzaje należności występowały jednak razem. Stosowano też różnego typu ulgi. Wpisowe płacili czytelnicy korzystający z bibliotek, m.in.: w Korytnicy Węgrowskiej (1 zł), Wilczyskach ( $50 \mathrm{gr}$ ), Witorożu (20 gr), Jeziorach-Sobieniach $(1 \mathrm{zf})$ i Sobolewie $(1 \mathrm{zf})^{30}$. Abonament miesięczny kosztowat od $10 \mathrm{gr}$ (Radoryż, Żeliszew, Życzyn, Jedlanka, Skórzec, Sarnaki) do $50 \mathrm{gr}$ (Stoczek Węgrowski). W niektórych bibliotekach obowiązywał abonament tygodniowy (Marianów), dwutygodniowy (Seroczyn), kwartalny (Prostyń) i roczny (Gęś). Stosowano też formę wypożyczeń jednorazowych, m.in: w Staninie, Trzebieszowie, Maciejowicach $i$ Łomazach, pobierając od 5 do $10 \mathrm{gr}$ od wypożyczonego tomu lub książki. Mniej za korzystanie z bibliotek parafialnych płaciły dzieci i młodzież szkolna, np. abonament miesięczny w Wohyniu kosztował dla dorosłych - $20 \mathrm{gr}$, dla dzieci - 10 gr, w Żelechowie - odpowiednio 20 i $5 \mathrm{gr}$. W niektórych parafiach były one zwolnione od jakichkolwiek opłat. Nie płaciły też osoby ubogie oraz członkowie organizacji katolickich i religijnych, które partycypowały w utrzymaniu bibliotek parafialnych. Kaucje pobierano zazwyczaj od osób nieznanych bibliotekarzowi i łamiących regulamin biblioteczny. Książki wypożyczano najczęściej na okres 2 tygodni. Za ich przetrzymywanie pobierano niekiedy kary pieniężne.

Biblioteki parafialne były otwarte zazwyczaj tylko w niedziele i święta, rzadziej $w$ inne dni tygodnia, ale była też niewielka grupa bibliotek czynnych codziennie (m.in. Ulan, Prostyń, Kodeń, Milanów). Niektóre biblioteki, m.in. w Tuchowiczu, udostępnialy swe księgozbiory tylko w okresie zimowym.

Wierni korzystali z bibliotek parafialnych, jak się stwierdza w protokołach z wizytacji biskupich, na ogół chętnie ${ }^{31}$. Nie zawsze jednak biblioteki, ze względu na brak nowości i niewielką liczbę książek, zazwyczaj dawno już wyczytanych, były w stanie zaspokoić ich potrzeby. Wśród czytelników przeważała młodzież, która preferowala przede wszystkim beletrystykę i książki historyczne. Największą poczytnością cieszyły się utwory: H. Sienkiewicza, J.I. Kraszewskiego, W. Reymonta, M. Rodziewiczówny i W. Przyborowskiego. Starsi chętniej czytali książki religijne i $z$ dziedziny rolnictwa. Dużym powodzeniem w obu grupach cieszyła się hagiografia.

Wspólny wysiłek duchowieństwa i wiernych diecezji podlaskiej doprowadzłł do powstania wielu bibliotek parafialnych, które starały się, mimo różnorakich trudności, pomagać w podnoszeniu poziomu kultury religijnej. Efekty ich działalności byłyby z pewnością znacznie większe, gdyby akcja biblioteczna na terenie parafii, o co zabiegal DIAK w Siedlcach, byla bardziej skoordynowana. Biblioteki parafialne w wielu miejscowościach były często jedynymi placówkami bibliotecznymi o charakterze publicznym.

\section{Przypisy}

${ }^{1}$ M. Fulman, Czytelnictwo religijne, „Wiadomości Pasterskie" 1905, nr 8, s. 517-518. 
2 Tenże, Czytelnictwo i czytelnie parafialne, "Wiadomości Pasterskie" 1906, nr 9, s. 549.

${ }^{3}$ S. Gajewski, Społeczna działalność duchowieństwa w Królestwie Polskim 1905-1914, Lublin 1990, 5. 114 .

4 Tamże; Biblioteki oświatowe, Warszawa 1932, s. 49-62.

${ }^{5}$ S. Gajewski, op.cit., s. 87; Archiwum Diecezjalne Lubelskie, Akta Związku Katolickiego w Diecezji Lubelskiej 1907-1911, Rep. 60, IX, nr 3-35.

${ }^{6}$ Biblioteki oświatowe..., s. 49-62; Archiwum Diecezjalne Siedleckie (ADS), Akta Kurii Diecezjalnej Siedleckjej czyli Podlaskiej (AKDS), Akta ogólne. Wizytacje kanoniczne biskupie. Protokoły, W III 3, t. I-IX.

7 "Wiadomości Diecezjalne Podlaskie" 1918, nr 1, s. 7.

${ }^{8}$ List biskupów polskich do Duchowieństwa, "Wiadomości Diecezjalne Podlaskie" 1919, nr 5, s. 130-134.

9 Tamże, s. 133.

${ }^{10}$ Protokół Konferencji 5-ej Ks. ks. Dziekanów Diecezji Podlaskiej odbytej dn. 21 sierpnia 1919 roku w Kurii Biskupiej w Siedlcach pod przewodnictwem Ks. Henryka Przeździeckiego, Biskupa Podlaskiego, "Wiadomości Diecezjalne Podlaskie" 1919, nr 10, s. 224-225.

${ }^{11}$ ADS, AKDS, W III 3, t. I-V; Archiwum Państwowe w Lublinie, Starostwo powiatowe konstantynowskie, sygn. 60, k. 57.

12 Synod diecezjalny podlaski pod przewodnictwem... w Janowie R.P. 1923 w d. 28, 29 i 30 sierpnia odbyty, Siedlce 1923, s. 146.

13 Tamże, s. 254.

${ }^{14}$ M. Biernacka, Wsie drobnoszlacheckie na Mazowszu i Podlasiu, Wrodaw 1966, s. 155, $213-215$.

${ }^{15}$ P. Aleksandrowicz, Diecezja siedlecka czyli podlaska, Siedlce 1971, s. 242.

${ }^{16}$ Dominujący wpływ miał tu w przeszłości Kościół unicki. Po jego likwidacji przez władze carskie w 1875 r. doszlo do masowych prześladowań unitów i ich przymusowego nawracania na prawoslawie. Ludność unicka stawiała opór, doszło do przelewu krwi w Drelowie i Pratulinie. Część parafii przetrwała w męczeńskim oporze aż do 1905 r. Kres prześladowaniom religijnym położyl dopiero ukaz tolerancyjny cara Mikołaja II z 30 IV 1905 r. Blisko 200 tys. byłych unitów na Podlasiu i w Chełmskiem odstąpiło wówczas od prawosławia i przyjęło obrządek łaciński. Proces przechodzenia do Kościoła katolickiego trwał aż do czasów II wojny światowej.

${ }^{17}$ ADS, AKDS, Wizytacje kanoniczne biskupie. Kwestionariusze, W III 3b, t. II-III.

${ }^{18}$ ADS, AKDS, W III 3b, t. I-III.

19 Tamże.

20 Tamże.

${ }^{21}$ W 9 parafiach neounickich w styczniu 1939 r. bylo zaledwie 1750 wiernych (P. Aleksandrowicz, op.cit., s. 242).

${ }^{2}$ ADS, AKDS, W III 3, t. I-I, W III 3b, t. I-III.

23 Wysokość wydatków zamykała się w granicach: 18-679 乙ł (Bibiloteki oświatowe..., s. 51-61).

24 Półtoraroczne sprawozdanie z działalności biblioteki par. Przemienienia Pańsk. w Łukowie, Łuków 1935, s. nlb.; Sprawozdanie z dzialalności Biblioteki Par. Przem. Paŕskiego w Łukowie za rok 1937, Łuków 1938, s. nlb.

${ }^{25}$ ADS, AKDS, W III 3b, t. I-III; Biblioteki oświatowe..., s. 49-61.

${ }^{26}$ Sprawozdanie z działalności ..., s. nlb.

27 ADS, AKDS, W III 3b, t. I-III. 
${ }^{28}$ Sprawozdanie z działalności..., s. nlb.

${ }^{29}$ Synod diecezjalny podlaski..., s. 254.

${ }^{30}$ ADS, AKDS, W Ill 3b, t. I-III.

31 Tamże.

Tab. 1. Biblioteki parafialne w diecezji podlaskiej w $1928 \mathrm{r} .{ }^{*}$

\begin{tabular}{|c|c|c|c|c|c|}
\hline Lp & Dekanat & $\begin{array}{l}\text { Liczba } \\
\text { parafii }\end{array}$ & $\begin{array}{l}\text { Liczba } \\
\text { bibliotek }\end{array}$ & $\begin{array}{c}\text { Nazwa parafii posiadają- } \\
\text { cej biblioteke }\end{array}$ & $\begin{array}{l}\text { Liczba } \\
\text { tomów }\end{array}$ \\
\hline 1 & siedlecki katedralny & 11 & 7 & $\begin{array}{l}\text { Domanice } \\
\text { Mokobody } \\
\text { Niwiski } \\
\text { Oleksin } \\
\text { Seroczyn } \\
\text { Skórzec } \\
\text { Żeliszew }\end{array}$ & $\begin{array}{r}195 \\
123 \\
250 \\
80 \\
100 \\
334 \\
170\end{array}$ \\
\hline 2 & siedlecki św. Stanisława & 10 & 5 & $\begin{array}{l}\text { Krzesk } \\
\text { Krześlin } \\
\text { Pruszyn } \\
\text { Wiszniew } \\
\text { Zbuczyn }\end{array}$ & $\begin{array}{r}154 \\
260 \\
175 \\
230 \\
60\end{array}$ \\
\hline 3 & bialski & 11 & 1 & Biala Wola & 200 \\
\hline 4 & garwoliński & 11 & 4 & $\begin{array}{l}\text { Górzno } \\
\text { Jeziony-Sobienie } \\
\text { Marianów } \\
\text { Osieck }\end{array}$ & $\begin{array}{r}145 \\
20 \\
120 \\
60\end{array}$ \\
\hline 5 & janowski & 8 & 1 & Leśna & 232 \\
\hline 6 & liwski & 9 & 8 & $\begin{array}{l}\text { Czerwonka Liwska } \\
\text { Kąty } \\
\text { Kopcie }\end{array}$ & $\begin{array}{r}250 \\
43 \\
567\end{array}$ \\
\hline
\end{tabular}




\begin{tabular}{|c|c|c|c|c|c|}
\hline Lp & Dekanat & $\begin{array}{l}\text { Liczba } \\
\text { parafii }\end{array}$ & $\begin{array}{l}\text { Liczba } \\
\text { bibliotek }\end{array}$ & $\begin{array}{c}\text { Nazwa parafii posiadaja- } \\
\text { cej biblioteke }\end{array}$ & $\begin{array}{l}\text { Liczba } \\
\text { tomów }\end{array}$ \\
\hline & & & & $\begin{array}{l}\text { Korytnica Wegr. } \\
\text { Liw } \\
\text { Wierzbno } \\
\text { Wiśniew } \\
\text { Wyszków }\end{array}$ & $\begin{array}{r}563 \\
563 \\
30 \\
86 \\
236\end{array}$ \\
\hline 7 & laskarzewski & 7 & 3 & $\begin{array}{l}\text { Gończyce } \\
\text { Korytnica Łask. } \\
\text { Maciejowice }\end{array}$ & $\begin{array}{r}137 \\
87 \\
745\end{array}$ \\
\hline 8 & losicki & 12 & 4 & $\begin{array}{l}\text { Górki } \\
\text { Hadynów } \\
\text { Przesmyki } \\
\text { Sarnaki }\end{array}$ & $\begin{array}{r}40 \\
40 \\
47 \\
330\end{array}$ \\
\hline 9 & łukowski & 14 & 8 & $\begin{array}{l}\text { kuków (Przem. Pańsk.) } \\
\text { Łuków (Podwyższenia } \\
\text { Krzyża) } \\
\text { Radoryż } \\
\text { Serokomla } \\
\text { Stanin } \\
\text { Trzebieszów } \\
\text { Tuchowicz } \\
\text { Zarzecz }\end{array}$ & $\begin{array}{r}150 \\
47 \\
693 \\
100 \\
657 \\
357 \\
295 \\
132\end{array}$ \\
\hline 10 & międzyrzecki & 11 & 2 & $\begin{array}{l}\text { Międzyrzec (św. Mikołaja) } \\
\text { Międzyrzec (św. Józefa) }\end{array}$ & $\begin{array}{l}22 \\
60\end{array}$ \\
\hline 11 & parczewski & 10 & 1 & Parczew & 560 \\
\hline 12 & radzyński & 9 & 5 & $\begin{array}{l}\text { Radzyń } \\
\text { Komarówka } \\
\text { Przegaliny } \\
\text { Ulan } \\
\text { Wohyń }\end{array}$ & $\begin{array}{r}200 \\
400 \\
38 \\
38 \\
805\end{array}$ \\
\hline
\end{tabular}




\begin{tabular}{|c|c|c|c|c|c|}
\hline LP & Dekanat & $\begin{array}{l}\text { Liczba } \\
\text { parafii }\end{array}$ & $\begin{array}{l}\text { Liczba } \\
\text { bibliotek }\end{array}$ & $\begin{array}{c}\text { Nazwa parafii posiadaja- } \\
\text { cej bibliotekę }\end{array}$ & $\begin{array}{l}\text { Licztua } \\
\text { tomów }\end{array}$ \\
\hline 13 & sokolowski & 11 & 6 & $\begin{array}{l}\text { Czerwonka Grochowska } \\
\text { Knychówek } \\
\text { Nieciecz } \\
\text { Rogów } \\
\text { Rozbity Kamień } \\
\text { Sokotów }\end{array}$ & $\begin{array}{r}50 \\
424 \\
34 \\
250 \\
420 \\
136\end{array}$ \\
\hline 14 & sterdyński & 10 & 3 & $\begin{array}{l}\text { Jabłonna } \\
\text { Łazówek } \\
\text { Skibniew }\end{array}$ & $\begin{array}{r}142 \\
50 \\
145\end{array}$ \\
\hline 15 & stężycki & 11 & 5 & $\begin{array}{l}\text { Koczów } \\
\text { Łysobyki } \\
\text { Ryki } \\
\text { Stężyca } \\
\text { Żabianka }\end{array}$ & $\begin{array}{r}250 \\
571 \\
250 \\
66 \\
75\end{array}$ \\
\hline 16 & terespolski & 12 & - & - & - \\
\hline 17 & węgrowski & 8 & 6 & $\begin{array}{l}\text { Kamionna } \\
\text { Miedzna } \\
\text { Prostyń } \\
\text { Sadowne } \\
\text { Stoczek Węgr. } \\
\text { Węgrów }\end{array}$ & $\begin{array}{l}300 \\
124 \\
265 \\
139 \\
640 \\
800\end{array}$ \\
\hline 18 & wisznicki & 9 & 1 & Rossosz & 20 \\
\hline 19 & whodawski & 11 & 2 & $\begin{array}{l}\text { Dothobrody } \\
\text { Wereszczyn }\end{array}$ & $\begin{array}{l}56 \\
60\end{array}$ \\
\hline 20 & żelechowski & 8 & 6 & $\begin{array}{l}\text { Borowie } \\
\text { Okrzeja } \\
\text { Stoczek kuk. } \\
\text { Wilczyska } \\
\text { Zwola } \\
\text { Żelechów }\end{array}$ & $\begin{array}{r}350 \\
105 \\
123 \\
523 \\
82 \\
899\end{array}$ \\
\hline & Razem & 203 & 78 & & 18577 \\
\hline
\end{tabular}

* Opracowano na podstawie ${ }_{n}$ Katalogu kościołów i duchowieństwa Diecezji Siedleckiej czyli Podlaskiej na rok 1929" (Siedlce 1929) 